\title{
DOCUMENTATION OF ARCHAEOLOGICAL SITES IN NORTHERN IRAQ USING REMOTE SENSING METHODS
}

\author{
E. Matoušková a ${ }^{*}, K$. Pavelka ${ }^{a}, K$. Nováček $^{b}$, L. Starková ${ }^{b}$ \\ ${ }^{a}$ Czech Technical University in Prague, Faculty of Civil Engineering, Thákurova 7, 166 29, Praha 6, Czech Republic \\ (eva.matouskova, pavelka)@ fsv.cvut.cz \\ ${ }^{\mathrm{b}}$ University of West Bohemia, Faculty of Philosophy and Arts, Sedláčkova 38, 306 14, Plzeň, Czech Republic
}

(knovacek, lstarkov)@kar.zcu.cz

Commission VI, WG VI/4

KEY WORDS: FORMOSAT-2, MULINEM, Remote sensing, Archaeology, Mesopotamia, Arbíl

\begin{abstract}
:
The MULINEM (The Medieval Urban Landscape in Northeastern Mesopotamia) project is aiming to investigate a Late Sasanian and Islamic urban network in the land of Erbil, historic province of Hidyab (Adiabene) that is located in the northern Iraq. The research of the hierarchical urban network in a defined area belongs to approaches rarely used in the study of the Islamic urbanism. The project focuses on the cluster of urban sites of the 6th-17th centuries A.D. This paper focuses on remote sensing analysis of historical sites with special interest of FORMOSAT-2 data that have been gained through a research announcement: Free FORMOSAT-2 satellite Imagery. Documentation of two archaeological sites (Makhmúr al-Qadima and Kushaf) are introduced. FORMOSAT-2 data results have been compared to historic CORONA satellite data of mentioned historical sites purchased earlier by the University of West Bohemia. Remote sensing methods were completed using in-situ measurements.
\end{abstract}

\section{INTRODUCTION}

\subsection{The MULINEM project}

The MULINEM (The Medieval Urban Landscape in Northeastern Mesopotamia) project is aiming to investigate a Late Sasanian and Islamic urban network in the land of Arbíl, historic province of Hidyab (Adiabene) that is located in the northern Iraq. The research of the hierarchical urban network in a defined area belongs to approaches rarely used in the study of the Islamic urbanism. The project focuses on the cluster of urban sites of the 6th-17th centuries A.D. in Adiabene, northeastern Mesopotamia. The urban landscape, once a constituent of prosperous Sasanian province and later becoming a part of the hinterland of the 'Abbasid megalopolis of Sāmarrā, eventually collapsed during the Ottoman era. The archaeological substance of the cities (ca. eighteen of them have been identified, see Figure 1) is largely in a very good state of preservation. The interpretation will concentrate on the issues of continuity of the ,Islamic ' urban network, its dynamism and resilience to the political and economic changes. The social structure reflected in the built environment of individual cities will also be in focus. The project aims to reconsider some widely accepted models of the Islamic town development based on the comparative material coming mostly from Syropalestine. The implementation of this multidisciplinary project will be reached by combination of three approaches: analysis of historical texts, remote sensing and archaeological survey. Historical texts are early Christian chronicles and account of the Arab geographers. Remote sensed data have played an important role in the identification of sites and is a main tool for the general layout study of the abandoned cities. The fieldwork aims to verify town plans resulted from the satellite imagery analysis and to obtain detailed data concerning the architectural remains. More information about the project can be found on project website mulinem.net.

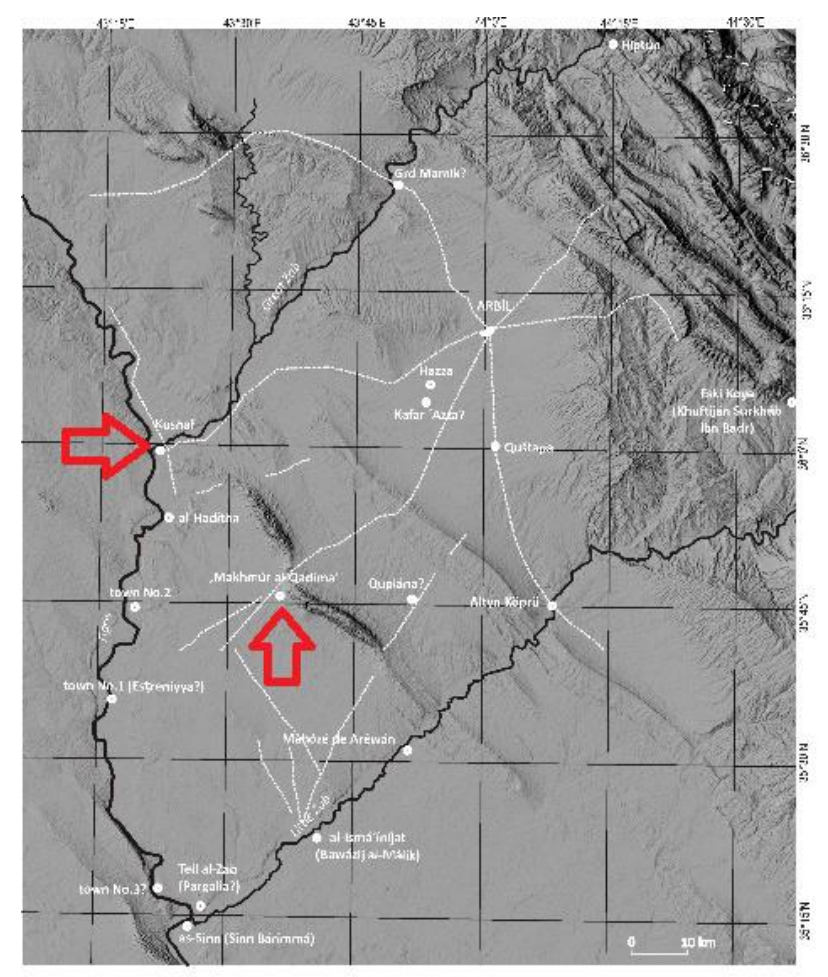

Figure 1 - Area of interest map with detected historical sites

\subsection{Remote sensing for archaeology}

Remote sensing, particularly the analysis of the satellite imagery, has appeared to be effective when documenting an archaeological sites (Keeney, 2015; Lasaponara 2012). Satellite data imagery has become a powerful tool for the historical sites documentation. (Menze, 2012; Mondino, 2012) Its main advantage is to have the possibility to analyse the site without 
actually visiting the area. This is especially important for unstable location where in-situ measurements can lead to serious safety risk for archaeologists and other people working on the site. Remote sensing methods cannot replace the fieldwork, but can give a fine picture about what is present on the historical site and can show the sites potential. With better resolution of recently launched satellites that goes up to several decimetres (QuickBird, GeoEye) more detailed analysis can be performed and the amount of gained information rises. The benefit of remote sensing lies also in the opportunity of temporal analysis of the location of interest (Pavelka, 2012), thus historical airborne/spaceborne data can be found in archives (e.g. USGS). The resolution of historical data is usually lower, so it is complicated to conduct a detailed analysis, but it is extremely useful for seeing the evolution of the specific historical site. The Czech Technical University in Prague, Faculty of Civil Engineering, Department of Geomatics has experienced several projects where remote sensing was used for historical sites documentation. (Hanzalová, 2013; Pavelka, 2010; Matoušková, 2011; Matoušková, 2012)

\subsection{Investigated archaeological site}

\subsubsection{Makhmúr al-Qadima}

The site was identified in the CORONA satellite imagery on the eastern outskirts of the current town of Makhmúr. The site is locally known as Makhmúr al-Qadíma (Fiey, 1965), but no mentions in the sources have been identified so far which might be connected with the site. The more than 100-hectar-large site is lying in the non-cultivated landscape and is, therefore, perfectly visible in the relief, but western part has been recently flattened due to town expansion and some areas on the south started to be cultivated few years ago. The probably nonfortified settlement area comprises several tens of low mounds, some of them are of big dimensions and of regular plans and seem to be arranged into an unified urban pattern (see Figure 2). An outstanding structure - a large square enclosure (ca. $120 \mathrm{x}$ $120 \mathrm{~m}$ ) consists of the 3-6 m high rampart - is located in the north part of the site (see Figure 3).

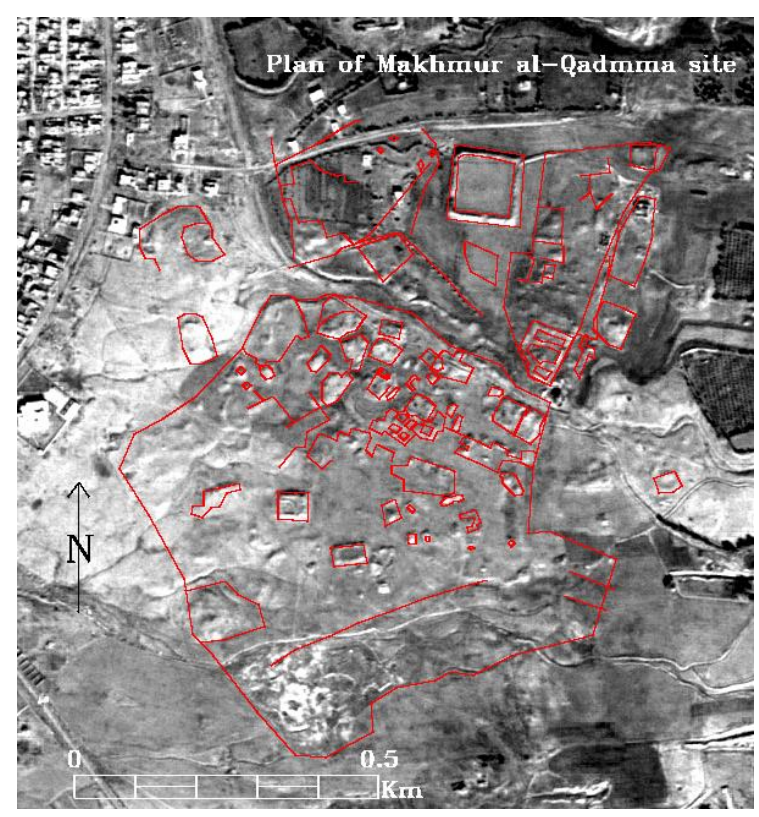

Figure 2 - Plan of Makhmúr al-Qadíma archaeological site based on FORMOSAT-2 band 1

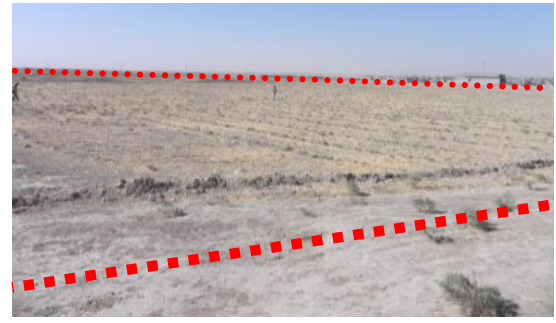

Figure 3 - A large square enclosure located in the northern part of the site as seen on site

Inside and in surroundings of the enclosure could be collected only Sasanian pottery. South of the enclosure, two other square mounds are visible: both of them are remains of masoned building complexes (see Figure 4) from which the northern one is extremely well preserved under the rubble, apparently till up the level of vaults.

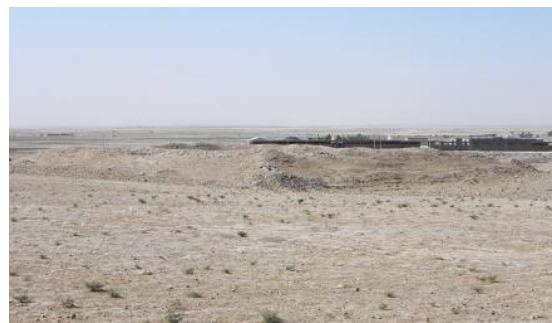

Figure 4 - Makhmúr al-Qadíma, the qasr from northeast

The regular plan of these complexes reminds of the standardized Umayyad castles (qusur in Arabic, sg. qasr) in the Levant area; the remains are covered by scatters of Early Islamic pottery. Indeed, the Sasanian and Early Islamic layers are placed shallowly under the surface elsewhere throughout the site; a broken storage jar with honeycomb and incised decoration, almost complete in fragments, was taken out by unknown person from a small illicit excavation (see Figure 5).

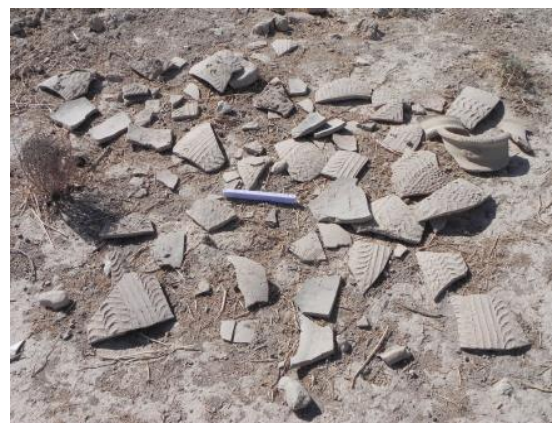

Figure 5 - Makhmúr al-Qadíma, illicitly excavated fragments of a Sasanian - Early Islamic storage jar

Observations in the western, mostly flattened part of the site brought pottery indications of Uruk, Neo-Assyrian(?) and Parthian periods, which suggests a more complex settlement history of this important site. The possible central character of this site is indicated also by an occasional find of a large cluster of cemeteries in the mountainous valley behind the Bayz Agha Dezaye Tomb. The ca. 10 hectares large burial area consists of one domed tomb and several thousands of grave stelae normally without any inscriptions or glyptic, which suggests an early dating of the site. 


\subsubsection{Kushaf}

The Neo-Assyrian site called Kasappa and Islamic town, whose citadel was mentioned by Abú al-Fidá in the beginning of the 14th C. A.D., occupied a strategic position on the south bank of Great Zab, near its confluence with Tigris. FORMOSAT-2 satellite imagery clearly shows a tripartite structure of the town: trigonal citadel (see Figure 6) and adjacent lower town, both situated on the tell, fortified on perimeter by a wall and a ditch (the citadel), were added by a dispersed settlement in the plain.

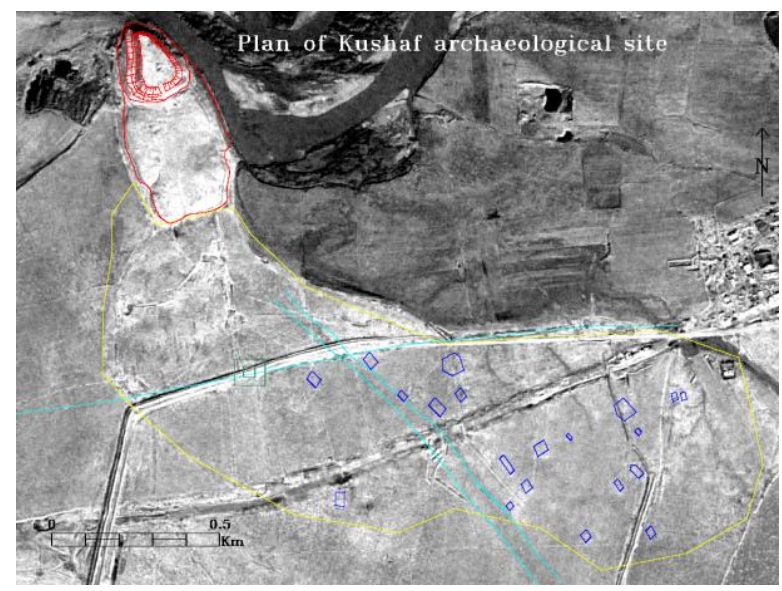

Figure 6 - Plan of Kushaf archaeological site based on FORMOSAT- 2 band 1

This 120-hectars-large area included a canal mouth and at least two large square structures (a mosque, a khan? or a water reservoir), one of them situated in the main communication corridor coming out from the lower town and heading south. The citadel was situated on the summit of the tell with impressive height (more than 40 meters - Figure 7).

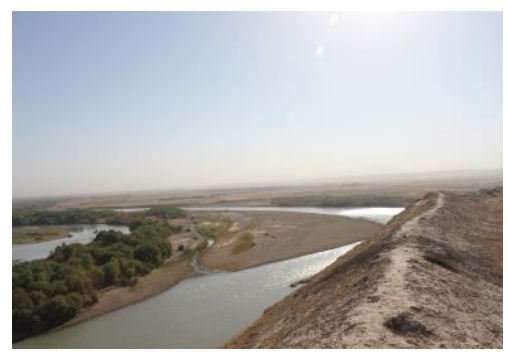

Figure 7 - View from the tell to the river (western view)

The area of citadel and lower town was recently damaged: the existing village was destroyed and its rubble removed, the surface was levelled and redundant material was bulldozed out over the edge of the tell (Figure 8). A new, wide track was dug into the southern slope of the citadel, as well as several large pits both in the citadel and in the lower town. Despite this heavy remodelling, several courses of the citadel's perimeter wall, masoned from limestone boulders, are still visible, mainly in the south side of the fortress.

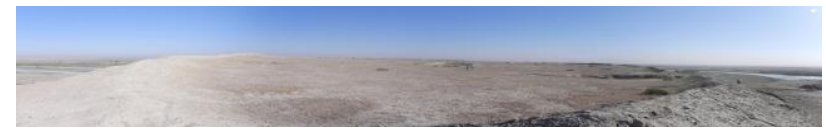

Figure 8 - Panoramatic view on the citadel of Kushaf from the SW corner
The south-eastern and south-western corners of the wall are not preserved; the course of the adjacent parts coming out from the tell may indicate towers originally set in the corners. The architectural remains of the south fortification are extremely important: the wall was added by ca. $37 \mathrm{~m}$ wide risalit going out forth the main wall for more than $5 \mathrm{~m}$ (Figure 9).

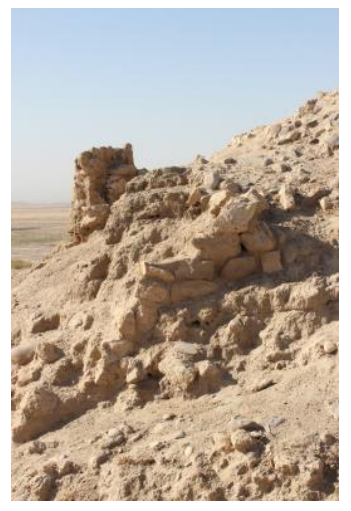

Figure 9 - View on a ruined structure in the southern front of the citadel, probably a gate

The risalit was flanked by two cylindrical towers, a gate with the entrance to the bridge across the ditch (Figure 10) was most probably situated axially between them (the locus was heavily damaged by the new track). Similar form of the gate flanked by a pair of cylindrical towers is common in the Early and Middle Islamic architecture in the East Mediterranean and Anatolian regions (e.g., Qasr al-Hayr al-Sharqi, Báb al-Futúh and Báb Zuwaila in Cairo or town gates in Diyarbakir), the pointing of the gate by risalite has the closest parallels to the Frankish military architecture in the Holy Land. Another architectural detail also strongly supports the idea of close relationship between the Kušáf citadel and Crusader / Ayyubid architecture of Levant: two limestone ashlars, the only ones preserved in the face of the eastern tower, have a rusticated surface, which is the element typical for Frankish, Ayyubid and early Mamluk architecture. The Neo-Assyrian, Hellenistic, Parthian, Early to Middle Islamic pottery occurs on the surface of the tell and lower town. The remains of the settlement in the plain are flat, not visible in the relief. The area is currently endangered by irrigation and intensive farming development. We failed to verify the location of the large enclosure south of the lower town; the site disappeared completely under a new, wide track and an irrigation rampart. A weak scatter of Sasanian - Early Islamic pottery was observed on the place.

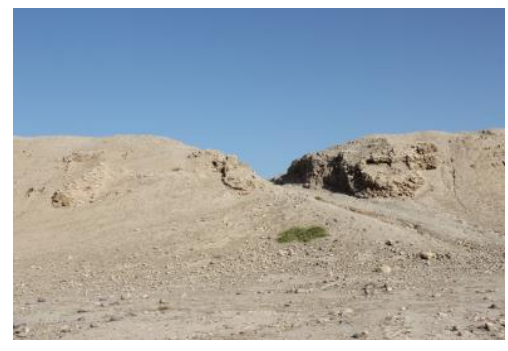

Figure 10 - View of the tell with entrance gate from south 


\section{DATA}

\subsection{CORONA}

The military CORONA system (operating from the 1960s to the beginning of the 1970s) that was driven by USGS is a great source of historical space borne data. It recorded the landscape before the recent, large-scale industrial changes and enable basic mapping of archaeological features. The earliest CORONA datasets possess the resolution about 12 meters, but since 1967 the resolution has improved up to about 1,8 $-2 \mathrm{~m}$ under ideal conditions. The most of features detected on the CORONA system is quite impossible to observe in medium resolution satellites which followed. Another big advantage of the later CORONA programme is the opportunity to work with a stereoscopic images. More information can be found on website http://space.jpl.nasa.gov/msl/Programs/corona.html

\subsection{FORMOSAT-2}

FORMOSAT-2 data that have been gained through a research announcement: Free FORMOSAT-2 satellite Imagery conducted by Centre for Space and Remote Sensing Research, National Central University. FORMOSAT has been launched on 21. 5. 2004. Four multispectral bands (blue, green, red, NIR) with $8 \mathrm{~m}$ resolution together with panchromatic band with $2 \mathrm{~m}$ pixel give fine images suitable for archaeological purposes. With the public tender 10 images (four archive and six newly acquired images) of different archaeological sites of the Adiabene area were purchased. Full image size is 24 x $24 \mathrm{~km}$ and only sections of original data have been used.

\section{RESULTS}

\subsection{Makhmúr al-Qadima}

\subsubsection{CORONA}

Used CORONA images were acquired on 16.8.1968 as a mission DS1104-2. These data were sharpened using 1,8 to 2,5 $\mathrm{m}$ resolution and thus provide relevant historical data. The archaeological site can be seen on Figure 11a. Figure 11b shows the location of interest with a plan of the site surveyed in the field. It is visible, that objects of interest are present.

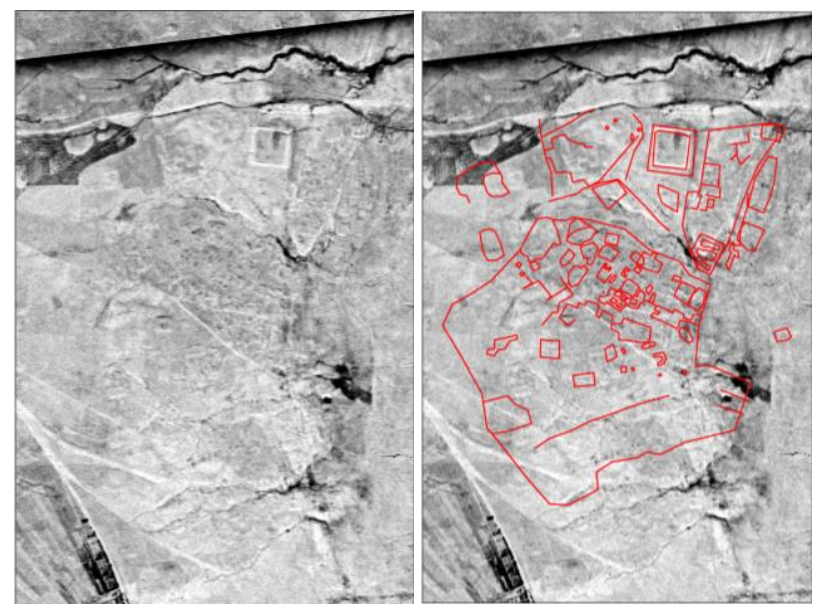

Figure 11a, b - Makhmúr al-Qadima - CORONA (acquired on 16.8. 1968) with an overlaid objects of interest on the right picture

\subsubsection{FORMOSAT-2}

FORMOSAT-2 image was acquired for the purpose of the MULINEM project in November 2014. Data acquisition was performed in autumn, because of the weather and vegetation conditions in this area. Objects of interest are better visible than in the CORONA images. This is due to a better resolution of the FORMOSAT-2 images and also due to better visibility of objects of interest in autumn images that are acquired when vegetation period begins. Images from high vegetation period (occurs in March, April) would have been interesting, but the probability of cloud free image in this time period is low. RGNIR synthesis provides a clear view to areas covered by vegetation.

\subsubsection{Band synthesis}

Different band synthesis is a powerful tool for preparing the data for a visual prospection. Joining bands together with histogram stretching and other image processing methods can highlight objects of interest and show information hidden in the image. Figure 12 shows synthesis of first three FORMOSAT-2 bands (RGB) and Figure 13 displays band 1, 2 and 4 (RGNIR)

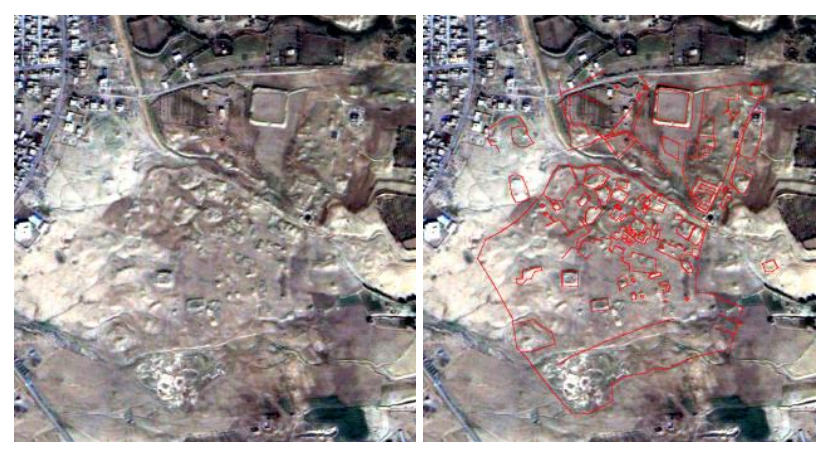

Figure 12 a,b Makhmúr al-Qadima - a RGB synthesis of the FORMOSAT-2 images (acquired on 2 11. 2014) with an overlaid objects of interest on the left picture

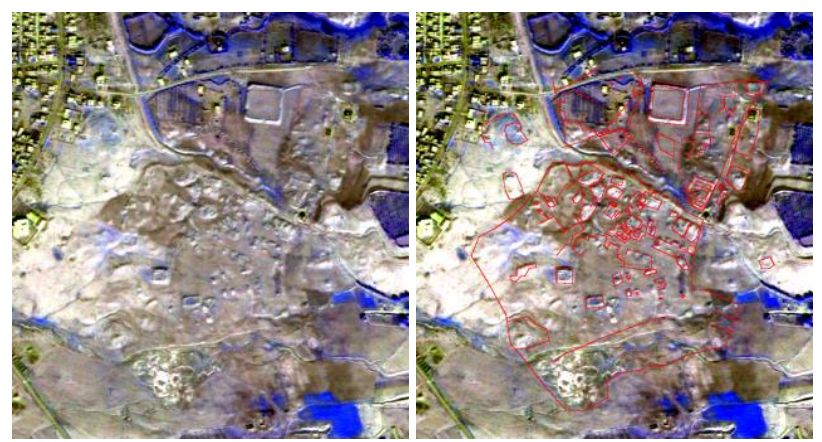

Figure 13 - Makhmúr al-Qadima - a RGNIR synthesis of the FORMOSAT-2 images (acquired on 2 11. 2014) with an overlaid objects of interest on the left picture

\subsubsection{Filtering methods}

Filtering methods are a great way to highlight linear objects. Two examples are shown on Figure 14 and Figure 15. 

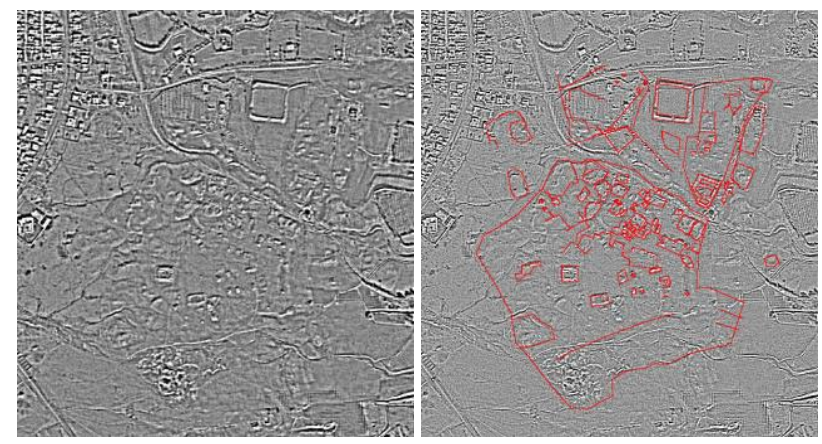

Figure 14a, b - A high pass 9x9 filter used on FORMOSAT-2 image of Makhmúr al-Qadima site with overlaid objects of interest on the left picture
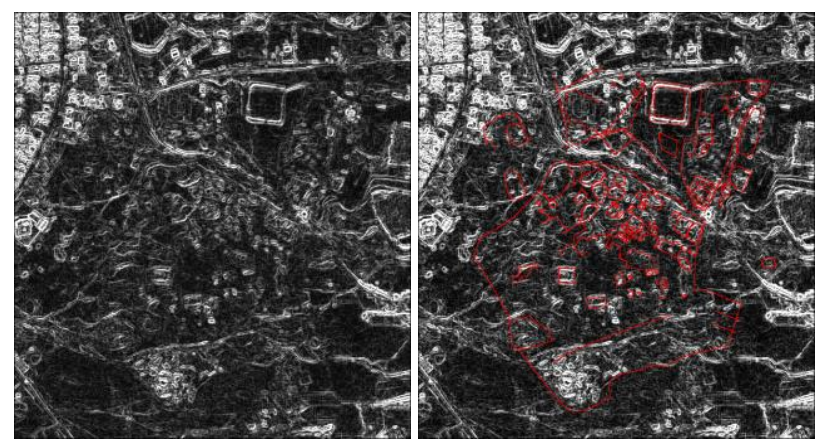

Figure 15a, b - A Sobel edge detector used on FORMOSAT-2 image of Makhmúr al-Qadima site with overlaid objects of interest on the left picture

\subsection{Kushaf}

\subsubsection{CORONA}

Used CORONA images were acquired on the 28.2.1967 as a mission DS1039-2 (Figure 16).
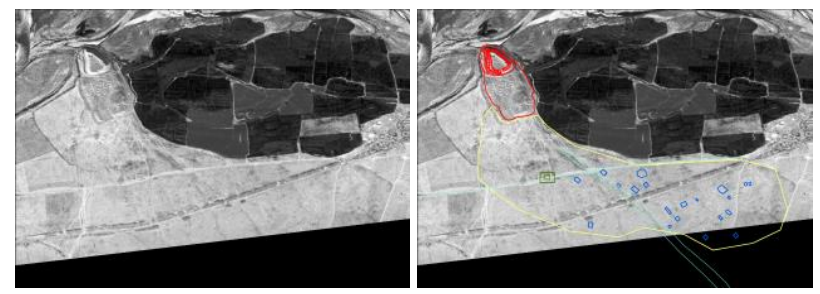

Figure 16a, $b$ CORONA (acquired on 28.2.1967) with an overlaid objects of interest on the right picture

\subsubsection{FORMOSAT-2}

FORMOSAT-2 images of the Kushaf area were acquired in October 2014. Smoothening of the lower tell area is visible when compared to CORONA images.

\subsubsection{Band synthesis}

Similar band combinations were performed as for the Makhmur al-Qadima site. Bands 1, 2 and 3 were joined into RGB image (Figure 17) and bands 1, 2 and 4 into a RGNIR image (Figure 18).

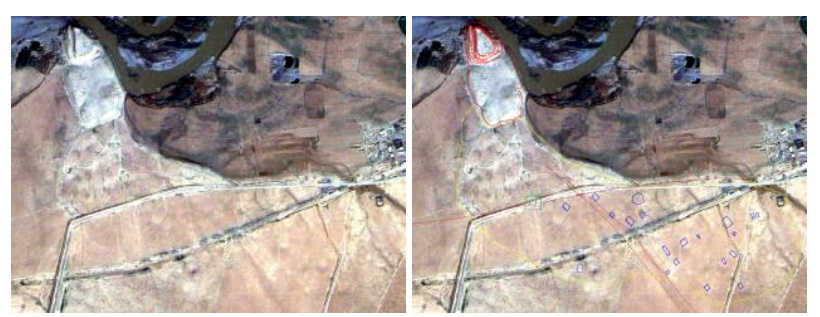

Figure 17a, b - Kushaf - a RGB synthesis of the FORMOSAT-2 images (acquired on 24.10.2014) with overlaid objects of interest on the left picture

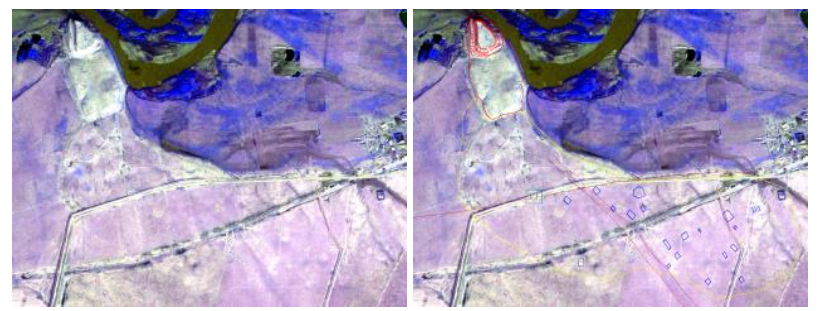

Figure 18a, b - Kushaf - a RGNIR synthesis of the FORMOSAT-2 images (acquired on 24.10.2014) with overlaid objects of interest on the left picture

\subsubsection{Filtering methods}

Figure 19 shows results of a high pass filter with a 9x9 kernel. Different kernel sizes were also tested. Sobel edge detector has been used and outcome can be seen on Figure 20.

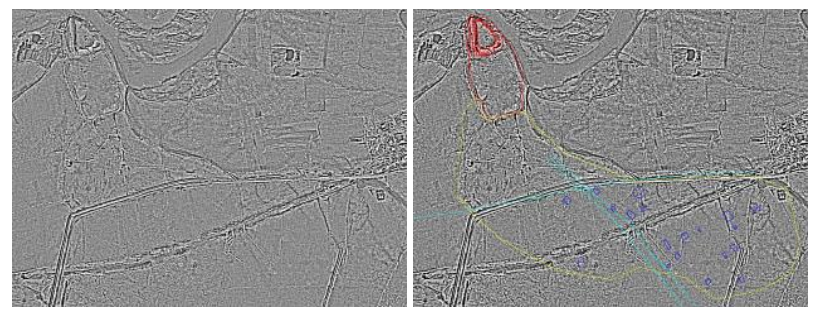

Figure 19a, b - A high pass 9x9 filter used on FORMOSAT-2 image of Kushaf site with an overlaid objects of interest on the left picture

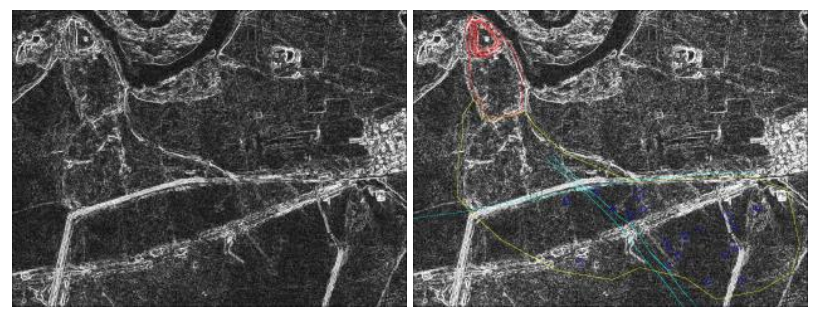

Figure 20a, b - A Sobel edge detector used on FORMOSAT-2 image of Kushaf site with an overlaid objects of interest on the left picture 


\section{CONCLUSION}

New FORMOSAT-2 satellite images were acquired for the MULINEM project. Two archaeological historical sites were investigated using these images (Makhmúr al-Qadíma and Kushaf) and compared with CORONA data and with in-situ measurements. It was found, that FORMOSAT-2 images with several pre-processing steps are suitable for remote sensing documentation of archaeological sites. FORMOSAT-2 image processing for documentation of archaeological object is not only band synthesis and filtering. The entire process consists of pre-processing methods (e.g. reflectance transformation, sharpening, histogram stretching) that result to an image that can then be visually or mathematically analysed. Various classification methods (supervised and unsupervised) were accomplished, but outcomes are not satisfactory. This is due to the nature of the steppe-like location where the majority of historical sites and features are hidden in dry steppe and do not differ enough from the major coverage. The failure of classification methods is because images show archaeological relief (brash cones) not construction relics with evident edges and ground plans. A hyperspectral image with sufficient spectral and spatial resolution may solve this problem, but these data are not at our disposal. Pre-processing and processing methods were performed in Excelis ENVI software.

In the MULINEM project every year areas of interest are visited by members of the team in order to gain in-situ measurements (geodetic survey, GPS, RPAS) and for the archaeological prospection. Unfortunately due to the specific political and safety situation in northern Iraq not all areas of interest can be visited and not all measurements can be performed. The region of northern Iraq has been very unstable in recent months with the growth of so called Islamic State in the area. In-situ measurements and investigations on site can become very dangerous. Remote sensing methods performs an irreplaceable role in documentation of archaeological sites located in politically unstable locations. Thanks to remotely sensed data it is possible to explore cultural heritage in desired areas without putting anyone at risk. Archaeological sites can be destroyed by local conflicts forever and it is highly necessary to document these extremely valuable cultural heritage sites for future generations.

\section{ACKNOWLEDGEMENTS}

The MULINEM (Medieval Urban Landscape in the Northeastern Mesopotamia) project is funded by the Czech Science Foundation.

\section{REFERENCES}

Fiey, J. M. 1965: Assyrie chrétienne: Contribution à l'étude de l'histoire et de la géographie ecclésiastiques et monastiques du nord de l'Iraq, Beyrouth, pp. 124, 127

Hanzalová, K. $\quad$ - Pavelka, K.: $\quad$ Archaeo-astronomical investigation of historical objects in Peru. In 13th International Multidisciplinary Scientific Geoconference SGEM 2013, Informatics, Geoinformatics and Remote Sensing, Conference Proceedings volume I. Sofia: STEF92 Technology Ltd., 2013, vol. 1, p. 321-328. ISSN 1314-2704. ISBN 978-954-91818-9-0.
Keeney, J., \& Hickey, R. (2015). Using satellite image analysis for locating prehistoric archaeological sites in alaska's central brooks range. Journal of Archaeological Science: Reports, 3, 80-89. Retrieved from www.scopus.com

Lasaponara, R., Masini, N., Holmgren, R., \& Backe Forsberg, Y. (2012). Integration of aerial and satellite remote sensing for archaeological investigations: A case study of the etruscan site of san giovenale. Journal of Geophysics and Engineering, 9(4), S26-S39. Retrieved from www.scopus.com

Matoušková, E. - Hanzalová, K.: Documentation of geoglyphs on Nazca Plain, Peru using remotely sensed data. In Proceedings of the 23rd CIPA Symposium. Praha: ČVUT, Fakulta stavební, Katedra mapování a kartografie, 2011, p. 358365. ISBN 978-80-01-04885-6.

Matoušková, E. - Hanzalová, K.: Documentation of geoglyphs in Peru Using VHR and SAR satellite data. In Proceedings of EARSeL Workshop Advances in Remote Sensing for Archaeology and Cultural Heritage Management. Gent: University of Gent, 2012, vol. 1, art. no. 1,

Menze, B. H., \& Ur, J. A. (2012). Mapping patterns of longterm settlement in northern mesopotamia at a large scale. Proceedings of the National Academy of Sciences of the United States of America, 109(14), E778-E787. Retrieved from www.scopus.com

Mondino, E. B., Perotti, L., \& Piras, M. (2012). High resolution satellite images for archeological applications: The karima case study (nubia region, sudan). European Journal of Remote Sensing, 45(1), 243-259. Retrieved from www.scopus.com

Pavelka, K. - Bukovinský, M. - Svatušková, J. - Hanzalová, K.: Documentation of the Abadoned Town La Ciudad Perdida In Peru Combining of VHR Satellite and Terrestrial Mesurement. In Proceedings The 30th EARSeL Symposium. Paris: Earsel, 2010, p. 126-137. ISBN 978-3-00-033435-1.

Pavelka, K. - Matoušková, E.: From declassified satellite images to VHR data; temporal analysis of city growth. In Proceedings of 1st Workshop on Temporal Analysis of Satellite Images. Paris: Earsel, 2012, p. 150-158.

Research Announcement: Free FORMOSAT-2 Satellite Imagery. CENTER FOR SPACE AND REMOTE SENSING RESEARCH, National Central University. Center for Space and Remote Sensing Research, National Central University [online]. Taiwan, 2014 [cit. 2014-10-09]. Available from: http://www.csrsr.ncu.edu.tw/FS2CFP/ 